\title{
Monitoring and Evaluation in Conservation: a Review of Trends and Approaches
}

\author{
CAROLINE STEM, * RICHARD MARGOLUIS, NICK SALAFSKY, AND MARCIA BROWN \\ Foundations of Success, 4109 Maryland Avenue, Bethesda, MD 20816, U.S.A.
}

\begin{abstract}
There is growing recognition among conservation practitioners and scholars that good project management is integrally linked to well-designed monitoring and evaluation systems. Most conservation organizations have attempted to develop and implement monitoring and evaluation systems, often with mixed results. One problem seems to be that organizations are trying to build their systems from scratch, overlooking lessons learned from the many efforts to develop useful and practical monitoring and evaluation approaches. Thus, we undertook a review of monitoring and evaluation approaches in conservation and other fields including international development, public bealth, family planning, education, social services, and business. Here, we present our results for the field of conservation. We categorized the considerable variety of monitoring and evaluation approaches into four broad purposes: basic research; accounting and certification; status assessment; and effectiveness measurement. We focus bere on status assessment and effectiveness measurement. Specific lessons that emerged follow: different monitoring and evaluation needs require different approaches; conceptual similarities are widespread among prevailing approaches; inconsistent language impedes communication; confusion among monitoring and evaluation components binders practitioner ability to choose the appropriate component; and monitoring only quantitative biological variables is insufficient. We suggest that the conservation community continue support of collaborative initiatives to improve monitoring and evaluation, establish clear definitions of commonly used terms, clarify monitoring and evaluation system components, apply available approaches appropriately, and include qualitative and social variables in monitoring efforts.
\end{abstract}

Key Words: adaptive management, management effectiveness, status assessment

Monitoreo y Evaluación en Conservación: una Revisión de Tendencias y Métodos

Resumen: Entre los practicantes y estudiosos de la conservación bay el reconocimiento creciente de que la buena gestión de proyectos está ligada integralmente a sistemas de monitoreo y evaluación bien diseñados. La mayoría de las organizaciones de conservación han intentado desarrollar e implementar sistemas de monitoreo y evaluación, a menudo con resultados mixtos. Un problema parece ser que las organizaciones están tratando de construir sus sistemas a partir de cero, sin considerar lecciones aprendidas de los muchos esfuerzos para desarrollar métodos de monitoreo y evaluación útiles y prácticos. Por lo tanto, bicimos una revisión de métodos de monitoreo y evaluación en conservación y otros campos incluyendo desarrollo internacional, salud pública, planificación familiar, educación, servicios sociales y negocios. Aquí, presentamos nuestros resultados para el campo de la conservación. Clasificamos la considerable variedad de métodos de monitoreo y evaluación en cuatro propósitos generales: investigación básica; contabilidad y certificación; evaluación de estatus y medidas de efectividad. Nos centramos en evaluación de estatus y medidas de efectividad. Las lecciones específicas que emergieron incluyen: necesidades diferentes de monitoreo y evaluación requieren métodos diferentes; hay similitudes conceptuales en todos los métodos prevalecientes; el lenguaje inconsistente bloquea la comunicación; la confusión entre componentes de monitoreo y evaluación limita la babilidad de practicantes para elegir el componente apropiado y el monitoreo de solo variables biologicas cuantitativas es insuficiente. Sugerimos que la comunidad de conservacionistas continúe con el apoyo de iniciativas de

\footnotetext{
${ }^{*}$ Current address: 17 Avery Street, Saratoga Springs, NY 12866, U.S.A., email caroline@fosonline.org

Paper submitted December 22, 2003; revised manuscript accepted July 21, 2004.
} 
colaboración para mejorar el monitoreo y la evaluación; establecer definiciones claras de términos usados comúnmente; clarificar componentes de sistemas de monitoreo y evaluación; aplicar métodos disponibles apropiadamente e incluir variables cualitativas y sociales en los esfuerzos de monitoreo.

Palabras Clave: efectividad de gestión, evaluación de estatus, manejo adoptivo

\section{Introduction}

Monitoring and evaluation (M\&E) has taken on increasing importance as the conservation community has faced a continuing struggle to demonstrate progress made toward protecting the earth's biological resources. Practitioners and scholars in conservation recognize that good management goes beyond implementation-effective management is integrally linked to well-designed monitoring and evaluation systems (e.g., Margoluis \& Salafsky 1998; Hockings et al. 2000; Woodhill 2000). Monitoring and evaluation can provide public and internal accountability and help demonstrate impact, both increasingly important functions in the current climate of budgetary constraints (Hockings et al. 2000; Sawhill \& Williamson 2001). Monitoring and evaluation answers questions related to how well a project or strategy is working and identifies the conditions under which a conservation action is likely to succeed or falter (Hatry 1999; Blann \& Light 2000). Moreover, M\&E can serve as an early warning system for potential problems and lead to ideas for potential remedial actions (Hatry 1999; Rigby et al. 2000). In essence, M\&E forms the basis for improved decision making.

Although conservation is a relatively new discipline, numerous efforts have been made to develop useful and practical monitoring and evaluation systems, often with mixed results. A primary problem seems to be that organizations are trying to build their systems from scratch, overlooking many lessons learned from a long history of efforts to develop useful and practical monitoring and evaluation approaches in conservation and other fields. Consequently, we undertook a review of M\&E approaches not only in conservation, but also in the fields of international development, public health and family planning, education and social services, and business. Our objective was to learn from the experiences of practitioners in these fields in measuring the success of their interventions. We hope to encourage the conservation community to look within and outside its boundaries to make the most of what others have learned, and ultimately, to improve programmatic efficiency and effectiveness. We present one part of this overall research, providing a historical review of different M\&E approaches in the field of conservation and distilling some important lessons. (For a description of the overall study and more detailed results, see http://www.fosonline.org.)

\section{Methods}

We reviewed more than 100 publications (including organizational documents and reports, Web sites, journal articles, and books) from the field of conservation as part of our overall review of more than 350 sources from all fields. (A database with information on many of these publications is available at http://www.fosonline.org). We concentrated primarily on M\&E literature related to project and program evaluation. In addition, we interviewed key informants from four different conservation institutions to identify major approaches and innovations in M\&E and to obtain recommendations on key publications to review.

We analyzed the literature to identify different approaches and key trends in conservation M\&E. We define a monitoring and evaluation approach as a specific process for doing M\&E, which is generally accompanied by a series of steps or guidance. As such, the same approach could incorporate biological data, social data, or a combination of the two. Thus, the primary distinction between approaches lies in the steps that comprise the approaches, not in the data that feed into them. Theoretically, an approach would also not vary by whether the data come from "western" scientific or indigenous sources. In reality, however, approaches that rely strictly on indigenous data sources are probably less likely to be formally published. As a result, this review focuses on more formal systems.

We operated under the implicit assumption that doing good M\&E leads to better decision making and therefore improved conservation. Various publications document specific cases where this has occurred (U.S. Environmental Protection Agency 1999; Hockings 2003; Hockings et al. 2000; Margoluis et al. 2001). It was beyond the scope of this research, however, to assess how successfully different M\&E approaches have been implemented and whether they have resulted in improved conservation.

There is an immense amount of literature on M\&E, especially informal literature from nongovernmental organizations (NGOs), programs, donors, and governments. Our review focused on all these sectors, but we found the greatest amount of documentation in the NGO community. This is likely because NGOs are usually responsible for project implementation. Although our review was extensive, our primary aim was not to be exhaustive, but 
rather to represent the major approaches and innovations documented in the literature.

\section{Evolution of M\&E Approaches in Conservation}

Within the conservation community, there is little clarity about the different functions evaluation fulfills or the conditions under which different types of evaluation are most appropriate. Evaluation approaches vary by context and stakeholder interests, thus serving multiple and often overlapping purposes, including knowledge generation, program improvement, accountability, transparency, resource allocation, advocacy, and impact assessment. We modified Mark et al.s (2000) framework to identify four main, albeit somewhat overlapping, purposes of evaluation: basic research, accounting and certification, status assessment, and effectiveness measurement. These purposes coincide with those widely agreed on by evaluation specialists (e.g., Chelimsky \& Shadish 1997; Patton 1997; Mark et al. 2000), although others exist (Hockings 2003).

Evaluation for basic research encompasses the gathering or generation of knowledge about a subject to gain a better understanding of the topic. Evaluation for accounting and certification considers whether an organization or program is fulfilling its obligations to donors, the public, the government, or some other enforcement entity. Evaluation for status assessment involves assessing the condition or status of a particular conservation entity (such as species, population, and ecosystem), generally irrespective of a specific intervention designed to affect the variable. Status assessment gives a reading of where a conservation entity is at a particular point in time.

In contrast to status assessments, evaluations for measuring effectiveness are necessarily linked to discrete interventions used by specific actors. (See Salzer and Salafsky [2003] for an in-depth discussion of M\&E for assessing status and M\&E for measuring effectiveness.) Evaluation for measuring effectiveness can be divided into two broad categories: impact assessment and adaptive management. Impact assessments are generally one-time assessments, often undertaken when a project is complete, to determine how well the project performed. Impact assessments can also include predictive assessments that evaluate the appropriateness of a potential intervention. Adaptive management is an iterative process that involves the integration of project design, management, and monitoring to systematically examine interventions to adapt and learn (Salafsky et al. 2001). The ultimate goal of adaptive management is to adapt and learn to improve an ongoing project or intervention.

Using this categorization, we created an evolutionary tree (Fig. 1) of different M\&E approaches to trace the development of fundamental ideas and how they influenced later ideas. We focused on key approaches (characteristics outlined in Table 1) that fall under status assessment and measuring effectiveness because they are the ones most commonly used by conservation managers for programmatic evaluation.

\section{Approaches for Status Assessment}

To understand our environment and to protect its resources, conservation managers need to be able to measure what they are trying to conserve. They need to know the status of and potential threats to biodiversity to make informed decisions about where to focus their conservation efforts. Evaluation for status assessment includes approaches such as population monitoring, rapid assessments, state-of-the-environment monitoring, report cards, and scorecards.

Status assessment in conservation has its roots in the late 1890s, when researchers began to use population monitoring as a means to determine how populations of various species change over time. Today, population monitoring is still an important approach for monitoring the status and distribution of species and for identifying potential threats to their survival.

Although approaches such as population monitoring have been key to generating conservation knowledge and tracking changes, they are generally too time consuming and expensive to be feasible approaches for much program and site-level status assessment. Around 1990 conservation organizations began to employ a more practical alternative for characterizing vegetation types and species: rapid assessments. These approaches offered the promise of gathering a great deal of key, targeted data in a short period of time. Conservation International has been a pioneer in rapid assessment approaches. The organization's Rapid Assessment Program, developed in 1990, was designed to fill gaps in regional knowledge of biodiversity hotspots and to provide biological information quickly to encourage timely conservation action (Conservation International 2001). Other organizations, such as The Nature Conservancy (TNC), World Wide Fund for Nature (WWF International), and World Wildlife Fund (WWFUS), have used rapid assessment methods to prioritize conservation actions or assess the status of the areas in which they work (e.g., Sayre et al. 2000; Ervin 2002). The main advantage to rapid assessment is that it yields a biodiversity conservation snapshot in a relatively short period of time. A concern, however, is that to gather information quickly the scope and sample size of rapid assessments are usually limited. Consequently, the reliability of conclusions is also limited.

Another early effort to systematically document the status and change in environmental conditions is the tracking of national environmental indicators through stateof-the-environment monitoring. These macro indicators give a general sense of where a country or region is in terms of key environmental variables, but they are generally not linked to specific interventions. Some early and well-known examples of this type of monitoring date to 

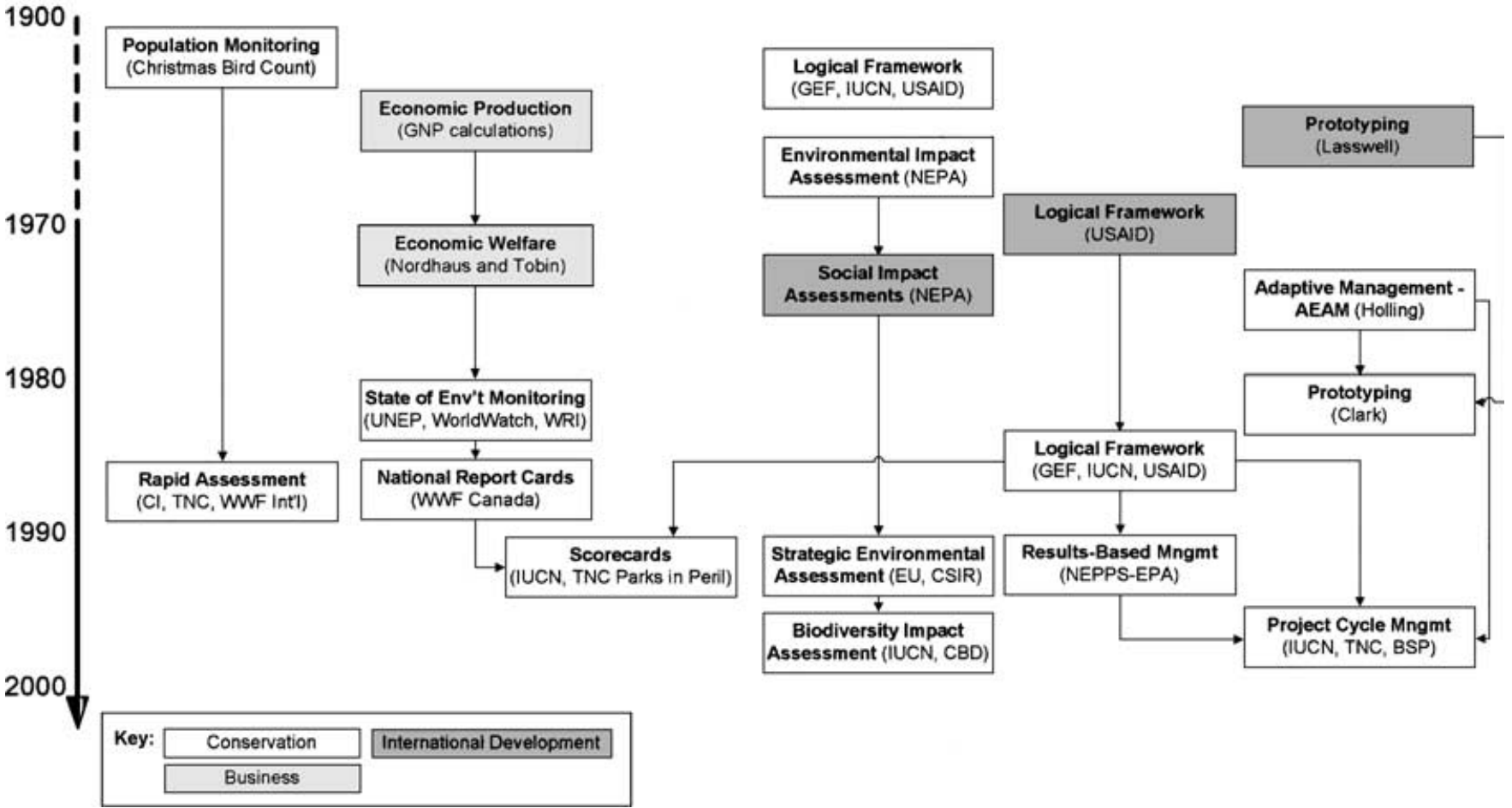

Figure 1. Conservation evaluation evolutionary tree. Each box contains a general MEE approach or tool and a key person or organization involved in its use or development. The placement of the boxes corresponds to the approximate period in which the approach was developed, although in many cases these approaches are still used today. Arrows indicate bow approaches evolved from or influenced other approaches. Abbreviations: BSP, Biodiversity Support Program; CBD, Convention on Biological Diversity; CI, Conservation International; CSIR, CSIR Environmentek; EPA, U.S. Environmental Protection Agency; EU, European Union; GEF, Global Environment Facility; GNP, gross national product; IUCN, World Conservation Union; NEPA, National Environmental Policy Act; NEPPS, National Environmental Performance Partnership System; TNC, The Nature Conservancy; UNEP, United Nations Environment Program; USAID, U.S. Agency for International Development; WRI, World Resources Institute; WWF, World Wide Fund for Nature.

the mid-1980s, when organizations such as the Worldwatch Institute and the World Resource Institute began publishing global reports on the state of the environment (e.g., Worldwatch Institute 1984). Another more recent and ambitious collaborative initiative is the Millennium Assessment, established in 2001 in response to requests from parties to the Convention on Biological Diversity, the Convention to Combat Desertification, and the Convention on Wetlands (Millennium Ecosystem Assessment Secretariat, n.d.). Many countries and regions within countries have followed the national and international reporting trends with their own version of stateof-the-environment reports. For example, in 1990, Parks Canada published its first State of the Parks report (Parks Canada 1998).

State-of-the-environment indicators at the national and regional levels, when tracked over time, can offer insights into the impacts of policies and higher-level action on biodiversity conservation. In general, however, these indica- tors are not designed to demonstrate causality. Instead, they provide a rough barometer of where a country or region is at a particular point in time.

Some countries and conservation organizations have developed national report cards (with letter grades) as a tool to present data from state-of-the-environment monitoring. For example, WWF-Canada has used a progress report format to track Canada's advancement toward establishing an ecologically representative system of national protected areas. Similarly, Sierra Club offices in Canada and the United States have used report cards to indicate how politicians and provinces or states are doing on key environmental issues. Technically, national report cards are a special format for presenting indicators from stateof-the-environment monitoring. They serve primarily as communication and advocacy tools and provide a compelling, easily understood format for presenting higherlevel indicators and encouraging the public and policy makers to take action. 


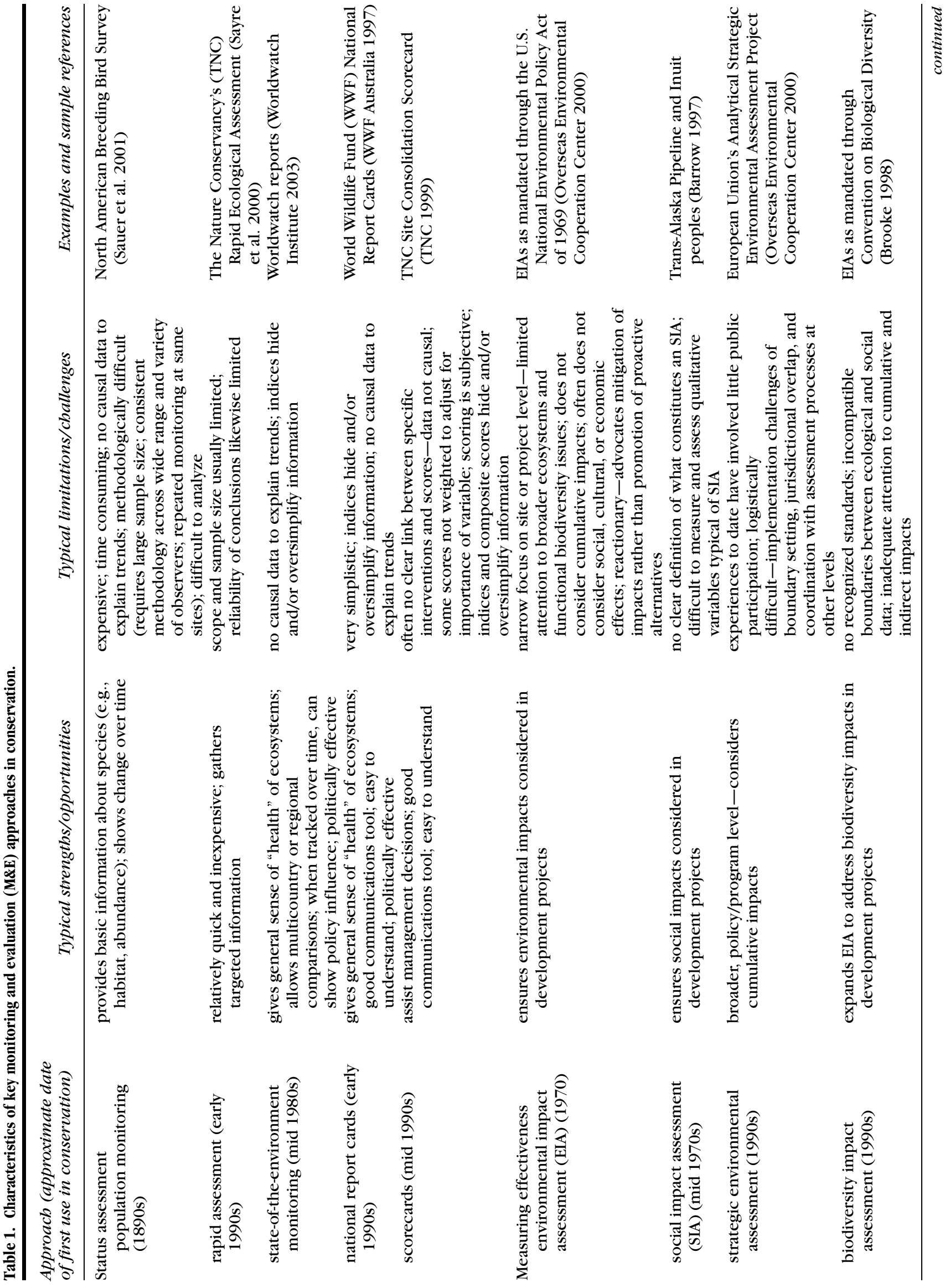




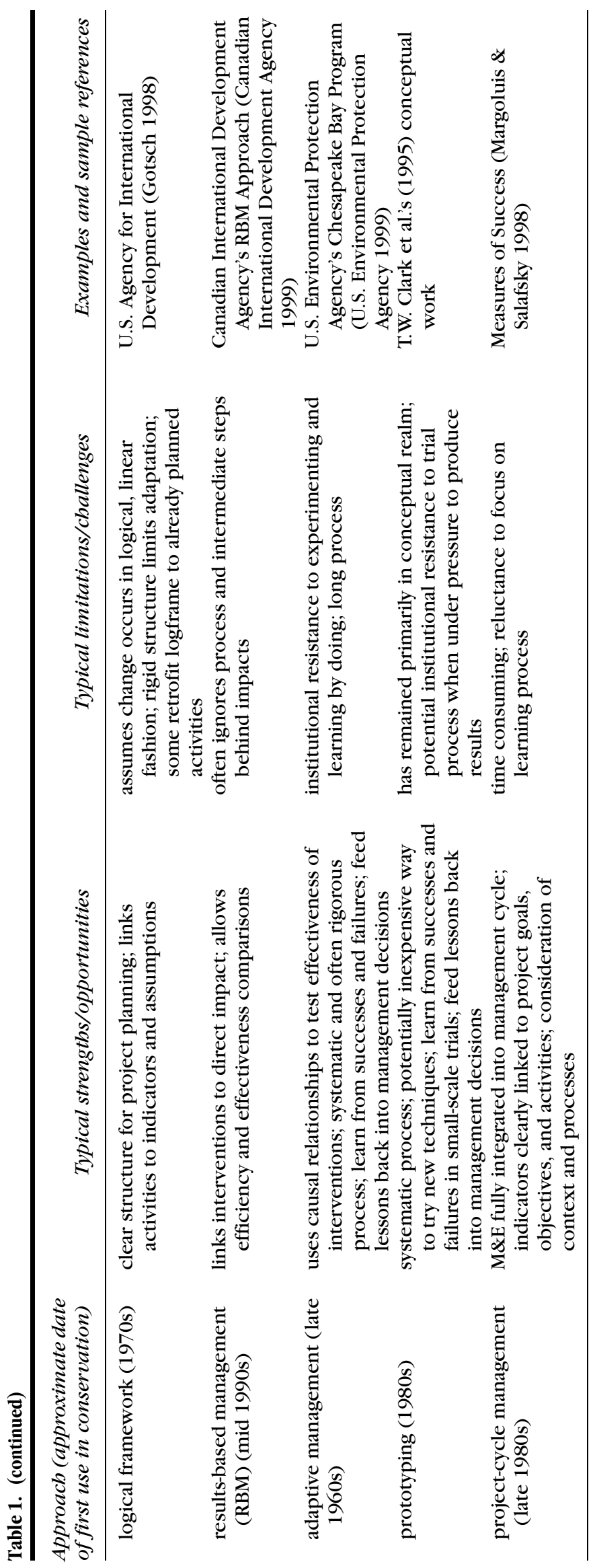

In the mid 1990s, conservation organizations, cognizant of the potential of scoring systems, developed scorecards to structure assessments of their site-level activities. Scorecards are technically not an M\&E approach; rather, they are a tool to facilitate M\&E. Depending on how scorecards are used, they can be a status assessment tool that reflects where a site or project is at a particular point in time (e.g., Ervin 2002) or they can be a measurement effectiveness tool that monitors sites over time and yields direct feedback for management decisions (e.g., TNC 1999). The Nature Conservancy has been a leader in scorecard development. Its Site Consolidation Scorecard, developed by the Parks in Peril Program with input from the U.S. Agency for International Development (USAID) and Latin American partners, helps to gauge a site's progress toward conservation goals. Because the criteria evaluated remain the same throughout the life of the project, the Site Consolidation Scorecard is an easy and relatively inexpensive means to assess progress over time (TNC 1999). The Nature Conservancy has also used a ranking tool for its 5-S framework for site-based conservation (Table 2). The 5-S approach (and its successor, the Enhanced 5-S Project Management Process) is a more comprehensive approach that draws on a scorecard tool in which staff categorically rank different elements associated with each of the five s's (systems, stresses, sources, strategies, and success). Other organizations have also been active in developing scorecard tools to assist in evaluating conservation interventions, especially in the context of protected areas (e.g., Ervin 2002; Stolton et al. 2002).

One limitation of many scorecards is that they do not directly link conservation interventions and conservation impact, although some do so implicitly. In addition, the creation of composite or average scores can disguise important information (M. Hockings, personal communication). Similarly, items scored often receive equal weight, even though they may not be equally important to achieving conservation success. Another problem with scorecards is that the rankings are often subjective. For example, what one person classifies as good, another might classify as fair. In the case of the Site Consolidation Scorecard, TNC has made significant progress in addressing this issue by defining its ranking categories more precisely.

\section{Approaches for Measuring Effectiveness}

As the previously discussed approaches indicate, M\&E is key to understanding a situation and assessing the status of specific variables. At the programmatic level, however, M\&E is most important for determining whether interventions are effective. Evaluation to measure effectiveness includes one-time impact assessments of an intervention and of adaptive management approaches. 
Table 2. Example of The Nature Conservancy's 5-S scorecard ranking tool.*

\begin{tabular}{|c|c|c|c|c|}
\hline Conservation targets & $\begin{array}{l}\text { Condition } \\
\text { grade }\end{array}$ & $\begin{array}{c}\text { Landscape context } \\
\text { grade }\end{array}$ & $\begin{array}{r}\text { Size } \\
\text { grade }\end{array}$ & Integrity rank \\
\hline Vernal pool grasslands & good & poor & good & fair \\
\hline Lower floodplain & fair & fair & fair & fair \\
\hline Upper floodplain: chinook salmon & fair & fair & fair & fair \\
\hline Upper watershed & fair & poor & good & fair \\
\hline Ione chaparral & fair & poor & poor & poor \\
\hline Blue oak woodland & fair & poor & good & fair \\
\hline Site biodiversity health rank & & & & Fair \\
\hline
\end{tabular}

*Source: Swenson et al. (2002).The 5-S scorecard allows for weighting of variables, but this particular example does not include weights.

\section{Impact Assessment}

In the late 1960s, public awareness of negative environmental impacts associated with development projects and industrial activities began to grow. In response to this public concern, the environmental impact assessment (EIA) process emerged. Although specific methods for conducting EIAs differ, the overall process involves identifying, predicting, and evaluating the potential effectsbeneficial and adverse-of development actions on the environment, then using the conclusions for planning and decision making. An impact assessment is usually conducted after the idea for the program or policy is developed but before it receives permission for implementation. The EIA's place in decision making in the United States solidified with the passage of the National Environmental Policy Act (NEPA) in 1969, which mandated EIAs for all federal-agency planning projects with significant environmental ramifications (U.S. National Environmental Policy Act of 1969). The 1970s and early 1980s saw the spread of the EIA throughout the world. The 1974 Organization for Economic Cooperation and Development (OECD) Declaration on Environmental Policy was the first international document to incorporate EIA (Overseas Environmental Cooperation Center 2000). Today, the EIA is widely endorsed internationally, including through multinational agreements such as Agenda 21 and the Convention on Biological Diversity.

Although the EIA has been key in minimizing and avoiding adverse environmental effects associated with development activities, it has been criticized for a number of reasons, including its (1) narrow focus on project- or site-level impacts and its limited attention to ecological and biodiversity impacts (Bagri \& Vorhies 1997; Brooke 1998); (2) reactionary nature that advocates mitigation of impacts rather than promotion of proactive alternatives (Brooke 1998); (3) tendency to be conducted once the project proposal has been developed, rather than in the early design stages when it is easier to make adjustments to avoid impacts; (4) lack of attention to the cumulative impact of numerous individual interventions at the site and regional levels (M. Hockings, personal com- munication); and (5) failure to consider social, cultural, or economic effects associated with the development action.

In response to these criticisms, various twists on the traditional EIA have emerged. For example, EIAs now frequently incorporate social impact assessments that examine how proposed development actions affect people and communities and the functioning of both. Strategic environmental assessment responds to problems associated with the project-specific nature of the EIA and the tendency of organizations to use the process too late in the design and planning phases. Strategic environmental assessment addresses environmental issues earlier in the project and also works at a broader program and policy level-a level that permits cumulative impacts from multiple development projects to be considered (Bagri \& Vorhies 1997). Finally, biodiversity impact assessment, inspired largely by the 1992 Convention on Biological Diversity, expands the scope of the EIA to consider effects on biodiversity. Each of these assessments helps to address weaknesses in traditional EIAs, but they are also subject to their own shortcomings. For example, measuring and assessing qualitative, subjective variables inherent in social impact assessments are particularly challenging tasks, although many social scientists have made great progress in reducing this subjectivity. There is also concern that, because of differences between the scope of a project decision and the scale of potential impacts, biodiversity impact assessments can result in inadequate analyses of indirect and cumulative impacts (Council on Environmental Quality 1993).

\section{Adaptive Management}

One of the earliest calls for measuring effectiveness in conservation came from C.S. Holling and several colleagues in the late 1960s. Working at the University of British Columbia's Institute of Resource Ecology, the group developed what they termed "adaptive environmental assessment and management" (C.S. Holling, personal communication), also known as adaptive management. "Adaptive management involves integrating project 
design, management, and monitoring to provide a framework for testing assumptions, adaptation, and learning" (Margoluis \& Salafsky 1998). Simply put, adaptive management is learning by doing-albeit in a systematic and purposeful way. Kai Lee (1993) explains, "Properly employed, this experimental approach produces reliable knowledge from experience instead of the slow, random [knowledge] gleaned from unexamined error." (Blann and Light [2000] compare definitions of adaptive management in the literature.) The work of the Locally Managed Marine Areas Network is an example of adaptive management applied across sites in Southeast Asia and the Western Pacific. Members of this network systematically test assumptions about their work to improve the success of their conservation efforts (Locally Managed Marine Areas Network 2003). Some examples of adaptive management approaches and tools include the logical framework, results-based management, and project-cycle management.

Approaches for measuring the effectiveness of conservation actions are more effective when preceded by and closely linked to a strong planning process and sound implementation (Margoluis \& Salafsky 1998; Blann \& Light 2000). An early example of an attempt to strengthen the project planning process is the logical framework (logframe), introduced by USAID around 1970. Development aid agencies quickly adopted the logframe, and its use in development became common throughout the 1970 s and 1980s. The logframe provided a clear structure for identifying a project's goals and objectives, the activities undertaken to achieve them, and the measures used to gauge progress toward those goals and objectives (Table 3).

Although development agencies have used the logframe extensively for their environmental projects, the logframe and its derivations (e.g., Ziel Orientierte Projekt Planung [ZOPP], which translates from German to "Objectives-Oriented Project Planning System") have not pervaded M\&E in the conservation field in general. Primary users in conservation include large, multilateral organizations like the World Conservation Union (IUCN) and the Global Environment Facility, as well as field-level conservation programs that are often required by donors to use a systematic project-planning process. Although the logframe facilitates sound planning, it has been heavily criticized for its rigid structure and its assumption that change occurs in a linear, logical fashion (Gasper 1999, as cited by den Heyer 2001).

In the mid to late 1990s, some environmental agencies, especially multilateral and national organizations, adopted a results-based management approach to $\mathrm{M} \& \mathrm{E}$ (also referred to as outcomes-based M\&E and performance M\&E). Around this time, there was a strong push for greater accountability. Donors and the public alike wanted to know that their resources were being used wisely. To prove that this was the case, organizations needed stronger M\&E systems-systems that were oriented toward measuring results, not just outputs. An outgrowth of this accountability movement was the enactment of the U.S. Government Performance Results Act of 1993 and similar legislation in other countries. Such legislation required agencies to demonstrate that their interventions were having the intended impact and that scarce resources were being used effectively. In the United States, the National Environmental Performance Partnership System (NEPPS), established in 1995, is an example of a results-based approach to environmental monitoring. The NEPPS was designed to strengthen protection by directing scarce resources toward improving environmental results, allowing states greater flexibility to achieve those results, and enhancing accountability to the public (U.S. Environmental Protection Agency 2003a). As part of the agreement, results should be performance measures that more directly reflect environmental quality. Conceptually, a results-based management approach offers a solid and complete approach to M\&E. In practice,

Table 3. Logical framework (logframe) as originally prepared for U.S. Agency for International Development.*

\begin{tabular}{|c|c|c|c|}
\hline Narrative summary & Objectively verifiable indicators & Means of verification & Important assumptions \\
\hline $\begin{array}{l}\text { Goal-the broader desired } \\
\text { state to which the project } \\
\text { contributes }\end{array}$ & measures of goal achievement & $\begin{array}{l}\text { sources of information and } \\
\text { method used to measure } \\
\text { indicator }\end{array}$ & $\begin{array}{l}\text { concerning long-term value } \\
\text { of program or project }\end{array}$ \\
\hline $\begin{array}{l}\text { Purpose-what the project, } \\
\text { within the time frame and } \\
\text { resources available, should } \\
\text { achieve }\end{array}$ & end of project status & $\begin{array}{l}\text { sources of information and } \\
\text { method used to measure } \\
\text { indicator }\end{array}$ & $\begin{array}{l}\text { affecting purpose-goal } \\
\text { linkage }\end{array}$ \\
\hline $\begin{array}{l}\text { Outputs-results obtained at } \\
\text { the project level through } \\
\text { activities using program } \\
\text { resources }\end{array}$ & $\begin{array}{l}\text { magnitudes of outputs and } \\
\text { planned completion date }\end{array}$ & $\begin{array}{l}\text { sources of information and } \\
\text { method used to measure } \\
\text { indicator }\end{array}$ & $\begin{array}{l}\text { affecting output-purpose } \\
\text { linkage }\end{array}$ \\
\hline $\begin{array}{l}\text { Inputs-resources that are the } \\
\text { project's raw materials }\end{array}$ & $\begin{array}{l}\text { nature and level of resources, } \\
\text { necessary cost, planned } \\
\text { starting date }\end{array}$ & $\begin{array}{l}\text { sources of information and } \\
\text { method used to measure } \\
\text { indicator }\end{array}$ & $\begin{array}{l}\text { assumptions affecting } \\
\text { inputs-outputs linkage }\end{array}$ \\
\hline
\end{tabular}

*Source: modified from Gotsch (1998). 
however, the approach can fall short when organizations focus primarily on results and pay little attention to the processes leading to those results.

Around the same time that results-based management emerged, some conservation organizations began to apply many of the principles associated with this approach to project-cycle management. These organizations recognized the need to understand whether their interventions were having the intended impact and to use the results to improve their programs. Specific approaches to project-cycle management differ, but the main principles are that M\&E should be fully integrated into the management cycle, rather than tacked on as an afterthought, and that indicators of success should be clearly linked to program goals, objectives, and activities (Herweg et al. 1998; Margoluis \& Salafsky 1998). Various organizations or programs, including TNC, WWF, the Biodiversity Support Program, and Foundations of Success, have used a project-cycle approach. Figure 2 shows an example of how one IUCN publication depicts the project cycle and the location of M\&E within that cycle. In addition, IUCN's World Commission on Protected Areas (WCPA) has developed a widely used evaluation framework for assessing protected-area management effectiveness. The framework is not an M\&E approach per se. Rather, it uses a project-cycle-based framework to communicate to protected-area managers which factors within the management cycle they should assess to determine

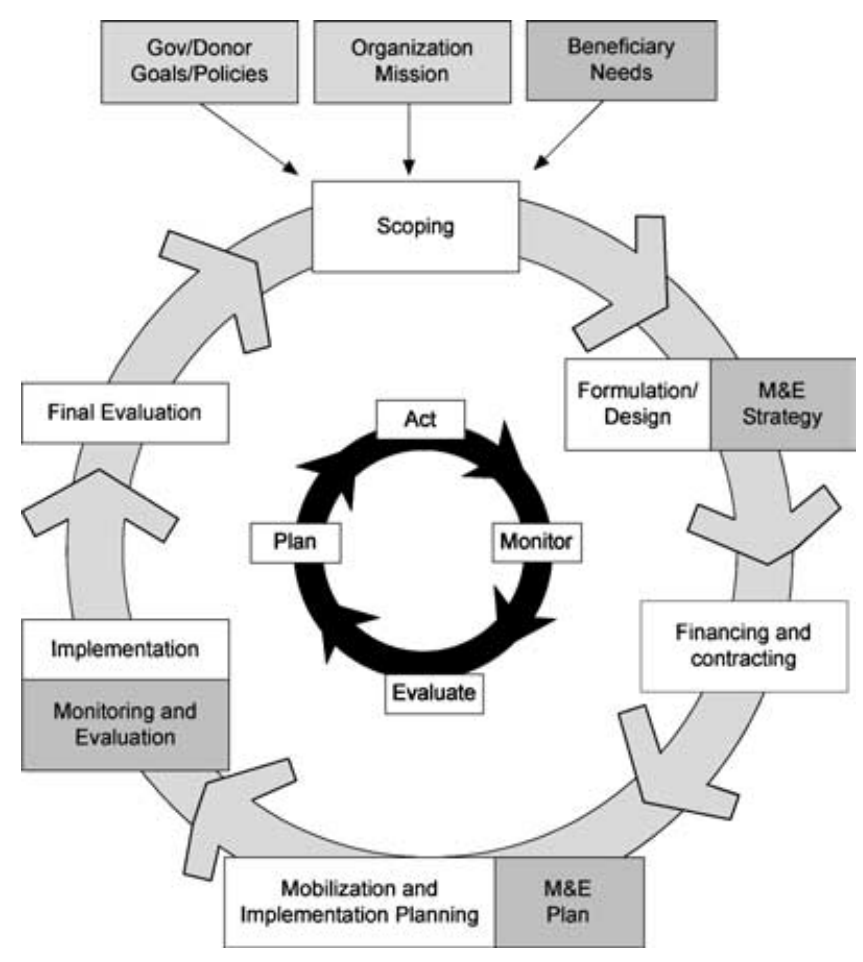

Figure 2. A program/project cycle used by the World Conservation Union, redrawn from Woodhill (2000). the effectiveness of their protected areas. (For information on monitoring and assessment systems for applying the WCPA framework, see Hockings et al. [2001].)

The exact project cycle used by each organization varies. Some cycles are simpler and contain fewer steps; others are more complex and comprehensive. Almost all cycles include the steps of planning, implementation, and monitoring. The more comprehensive cycles make other steps more explicit. For example, the Measures of Success approach adds a step requiring the development of project site conceptual models and another step focusing on the analysis and communication of information (Margoluis \& Salafsky 1998). Moreover, the approach explicitly emphasizes the continuous feedback of evaluation results into ongoing management decisions.

A main advantage of many project-cycle management approaches is that they emphasize the learning aspect of M\&E. Monitoring and evaluation is not a requirement imposed from above or added on after the project is in place-it is an opportunity for conservation managers to learn from and improve their interventions. Paradoxically, one of the greatest challenges to project-cycle management is the reluctance to focus on the learning process. Learning takes time, and most practitioners already find themselves overburdened by unmanageable workloads.

\section{Discussion}

By reviewing M\&E approaches, how they have evolved, and their key strengths and limitations, we were able to identify several general lessons for conservation: (1) different M\&E needs require different M\&E approaches; (2) prevailing approaches for M\&E share conceptual similarities; (3) inconsistent use of language in M\&E approaches impedes communication and understanding among organizations; (4) confusion among components of M\&E systems hinders practitioners' abilities to choose the components appropriate for their needs; and (5) monitoring only quantitative biological information is insufficientsocial, political, and cultural information, and qualitative data help provide a more complete understanding of what is happening at a site.

\section{Different M\&E Needs Require Different M\&E Approaches}

Conservation practitioners draw on many different approaches and tools for programmatic M\&E. Which approaches and tools practitioners should choose depends on whether their monitoring goal is to gain a general sense of the existing condition of biodiversity at a particular point in time (status assessment) or to know if their conservation interventions are having their intended effect (effectiveness measurement).

In the case of status assessment, M\&E approaches and tools generally involve measuring a set of indicators that 
give a general picture of a situation at one point in time or over various points in time. These approaches and tools tend to be indicator driven, measuring conservation variables independently of specific interventions. For example, many organizations use state-of-the-environment monitoring to show general trends in the overall status of conservation variables. Status assessment approaches are particularly useful for tracking higher-level trends and comparing these trends across regions and countries. The tools used in these approaches are often simple and straightforward (e.g., scorecards), and they communicate information in an effective, readily understood manner (e.g., national report cards). Approaches and tools for status assessment yield important political inputs that can help decision makers determine where to invest valuable resources. By focusing exclusively on measuring changes in a conservation target, however, status assessment approaches overlook important management processes and external factors that influence the ability to reach the target. Simply put, these approaches cannot adequately demonstrate probable cause-and-effect relationships.

In contrast, approaches and tools for measuring effectiveness tend to involve a more comprehensive process to measure whether specific conservation actions have produced the desired impact. With effectiveness measurement, there is explicit recognition of the link between programmatic goals, objectives, activities, and management processes and the indicators used to measure progress toward achieving conservation goals and objectives. Under these approaches, practitioners consider their measures in the broader context and strive to explicitly demonstrate likely cause-and-effect relationships. The appeal of approaches for measuring effectiveness is that they offer a means to determine, under varying conditions, which conservation interventions are effective and which should be avoided. This is critical information for practitioners who must decide how to best allocate scarce resources. The main challenge to these approaches, however, is that they are more time consuming. Another challenge relates to how some effectiveness approaches, such as results-based management, have been applied. In some cases, organizations focus exclusively on results and performance, with little or no attention to management processes or other variables that may affect an intervention's ability to achieve the desired impact. When applied in this way, effectiveness approaches, like status assessment approaches, cannot reliably attribute impact to programmatic interventions.

The main lesson here is that different approaches and tools will meet different needs; there is no one M\&E approach that fits all conservation efforts. Neither status assessment approaches nor effectiveness measurement approaches are inherently better or worse than the other. To determine which approach or tool is most appropriate, managers and practitioners must have a clear understanding of their monitoring needs. If the goal is to understand broader trends, status assessment approaches are most appropriate. If the goal, however, is to understand and improve specific conservation interventions, a status assessment approach is not sufficient-approaches for measuring effectiveness are required.

\section{Conceptual Similarities Are Widespread among Prevailing M\&E Approaches}

Despite the numerous competing M\&E approaches, there is a surprising amount of convergence among approaches within a specific purpose. For example, in the case of M\&E for status assessment, even though indicators vary, organizations are often trying to measure the same variables (e.g., deforestation, species survival, and habitat quality). With M\&E for measuring effectiveness, specific approaches, terminology, and sequencing for steps may differ, but the general steps and the fundamental principles underlying the various approaches are the same. For example, some might see a situation analysis as the first step in project development; others might undertake a situation analysis once the project goals and objectives have been established. Nevertheless the general concepts are the same.

Given that there is little conceptual difference among prevailing $M \& E$ approaches, there is a great opportunity to work toward common standards for how to do project and program M\&E and to agree on common indicators for measuring key variables. Some advantages of this type of collaboration include increased clarity on steps for conducting M\&E, shared understanding and use of terminology, better ability to identify appropriate indicators, greater ability to compare M\&E results across organizations, increased insight on the benefits and limitations of different M\&E approaches, and improved capacity to work with donors and meet monitoring requirements.

Some nascent efforts at collaboration have surfaced. For example, in the case of status assessment, largerscale cooperation is occurring through indicator standardization efforts, such as the regional and international initiatives on criteria and indicators for sustainable forest management. The Montreal Process, formed in 1994, is the criteria and indicators initiative with the largest geographical representation (The Montreal Process 1999). Member countries have worked at national and international levels to develop criteria and indicators for sustainable forest management and to obtain and report data on those criteria and indicators. An example of collaboration in M\&E for measuring effectiveness can be seen in the Conservation Measures Partnership (CMP; http://www.conservationmeasures.org), a recently formed alliance of practitioners who are interested in collaborating on M\&E. Their mission is "to transform the practice of biodiversity conservation by: a) developing common standards for the process of conservation and measuring conservation impact, and b) devising an 
audit process to measure conservation effectiveness and encourage the adoption of best practices" (CMP 2003a).

\section{Inconsistent Language Impedes Communication and Understanding}

Despite their conceptual similarities, prevailing approaches are not well understood across organizations, in large part because of language inconsistencies. For example, what one organization calls a result, another may call an outcome, and still another may call an impact. Likewise, given a particular situation, one organization might refer to deforestation as a threat to biodiversity; another might call it a pressure on a protected area. Although these distinctions may appear trivial, they have seriously hindered the ability of organizations to understand one another's M\&E systems and to communicate in a unified fashion.

Organizations are understandably invested in their systems, but the conservation community would greatly benefit from efforts to clearly define and cross reference the diverse range and use of terms. If conservation organizations, however, were to take this a step further-to agree on a standard language for common M\&E termsthe benefits would expand well beyond the conservation community. For example, such action would facilitate clearer communication with external audiences, including donors, general evaluation practitioners, and the public. It would also permit greater comparability of conservation actions across organizations and projects or programs. One effort along these lines is the "Rosetta Stone" being developed by CMP (2003b). The Rosetta Stone cross references how member organizations use different project management terms and concepts (e.g., conservation target, threat, strategy, and objective) and identifies similarities and differences. It also defines the main steps each organization uses in their project management cycle.

\section{Confusion among Components of M\&E Systems Hinders} Ability to Choose Appropriate Components

A basic and yet not trivial finding of our review is that organizations tend to confuse the purpose of different components of an M\&E system. This confusion is related to inconsistent language. Additionally, the purpose served by different M\&E components is not always clear; consequently, practitioners may use them for purposes for which they were not designed. For instance, some organizations have referred to the pressure-state-response (PSR) framework as their M\&E approach, when in reality, PSR is a conceptual framework that provides a template for understanding generic cause and effect relationships (Table 4). As such, PSR cannot serve as an M\&E approach without a process that specifies the steps and guidance for doing M\&E.
We have tried to clarify the purpose of different components of an overall M\&E system by proposing definitions for some key components: approaches, conceptual frameworks, evaluation frameworks, conceptual models, and tools (Table 4). Each of these components fulfills different functions. To use the components effectively, conservation practitioners need to understand those functions and how they relate to the overall M\&E process. Furthermore, practitioners must be specific about what they wish to accomplish before they can know whether they need an approach, a framework, a model, or a tool. For example, if one wants to know how to carry out M\&E, a tool such as a scorecard will not suit this need. Instead, an approach that provides specific steps and guidance is needed. The approach might include tools such as a scorecard, but it is the approach - not the tool-that explicitly specifies the steps to carry out the M\&E process.

\section{Monitoring Only Quantitative Biological Information is Insufficient}

Traditionally, conservation monitoring has meant looking at quantitative indicators of biological health. Although conserving biodiversity is the ultimate goal, most organizations now recognize the importance of looking beyond biological indicators when assessing ecosystem health. Evaluation activities for both status assessment and effectiveness measurement now frequently include the monitoring of social, economic, political, and cultural threats and opportunities that influence conservation. For example, ecological integrity is only one element of Parks Canada's protected-area assessment system. The organization also monitors historical and cultural resources, transportation, and the state of a place for people and community (Banff National Park of Canada 2003).

Similarly, there is increasing recognition of the importance of engaging stakeholders in project management, including M\&E. Much of this participatory movement is grounded in the social sciences and is covered more extensively in our review on M\&E in international development (see http://www.fosonline.org). Participation might include soliciting stakeholder input on program and evaluation design, implementation, analysis, and communication of results. Participation could also include volunteer or citizen monitoring. For example, the U.S. Environmental Protection Agency's Office of Water coordinates a large network of volunteer monitors who gather data for water bodies that might not otherwise be assessed and provide valuable water-quality information to decision makers (U.S. Environmental Protection Agency 2003b).

There has also been greater acceptance of and interest in qualitative methods and measures. Both social and biological monitoring have traditionally involved the quantification of variables, but social monitoring also often incorporates qualitative methods and measures that better 
Table 4. Proposed definitions of some common terms used in monitoring and evaluation (M\&E) for management effectiveness.

\begin{tabular}{|c|c|c|c|}
\hline M\&E approach & $\begin{array}{l}\text { a specific process for } \\
\text { doing M\&E, generally } \\
\text { accompanied by a } \\
\text { series of steps or } \\
\text { guidance }\end{array}$ & $\begin{array}{l}\text { An approach is one of two main } \\
\text { components of an M\&E system. } \\
\text { The other main component is a } \\
\text { conceptual framework. } \\
\text { An approach may also use an } \\
\text { evaluation framework and a variety } \\
\text { of tools to assist in the undertaking } \\
\text { of M\&E. }\end{array}$ & $\begin{array}{l}\text { enhanced 5-S project management } \\
\text { process (The Nature } \\
\text { Conservancy's Developing } \\
\text { Strategies Group et al. 2003) } \\
\text { environmental impact assessments } \\
\text { (U.S. National Environmental } \\
\text { Policy Act of 1969) } \\
\text { results-based management } \\
\text { (Canadian International } \\
\text { Development Agency 1999) } \\
\text { measures of success (Margoluis \& } \\
\text { Salafsky 1998) }\end{array}$ \\
\hline Conceptual framework & $\begin{array}{l}\text { a representation of } \\
\text { cause-and-effect } \\
\text { relationships in a } \\
\text { generic fashion }\end{array}$ & $\begin{array}{l}\text { A conceptual framework is one of } \\
\text { two main components of an M\&E } \\
\text { system. The other main component } \\
\text { is an approach. } \\
\text { Conceptual frameworks provide a } \\
\text { generalized representation of } \\
\text { reality used to develop specific } \\
\text { conceptual models (an evaluation } \\
\text { tool). }\end{array}$ & $\begin{array}{l}\text { pressure-state-response (PSR) } \\
\text { framework (Organisation for } \\
\text { Economic Co-Operation and } \\
\text { Development 1993) } \\
\text { driving-force } \\
\text { pressure-state-impact-response } \\
\text { (DPSIR) framework (Rigby et al. } \\
\text { 2000) } \\
\text { capital framework (World Bank } \\
\text { 1997) }\end{array}$ \\
\hline Evaluation framework & $\begin{array}{l}\text { a representation of the } \\
\text { management } \\
\text { processes and } \\
\text { expected results to be } \\
\text { considered in an } \\
\text { evaluation }\end{array}$ & $\begin{array}{l}\text { The application of an evaluation } \\
\text { framework is a step in an approach } \\
\text { to determine the management } \\
\text { processes and expected results that } \\
\text { should be considered. }\end{array}$ & $\begin{array}{l}\text { logical framework (Cracknell } \\
2000 ; \text { den Heyer 2001) } \\
\text { generic results chain (inputs } \rightarrow \\
\text { activities } \rightarrow \text { outputs } \rightarrow \\
\text { outcomes } \rightarrow \text { impacts) (den } \\
\text { Heyer 2001) } \\
\text { World Commission on Protected } \\
\text { Areas Framework for Assessing } \\
\text { Protected Area Management } \\
\text { (Hockings et al. 2000) }\end{array}$ \\
\hline
\end{tabular}

capture insight into some variables, such as perceptions, values, and experiences. Conservation still places a heavy emphasis on quantifying measures, but qualitative methods and measures have emerged as valid and important means of assessing variables.

The recognition that conservation monitoring should go beyond quantitative biological information reflects the fact that conservation takes place in a complex context influenced by human populations. To truly assess the impact of interventions, conservation managers cannot consider them in isolation of these human populations. For example, in status assessment, it is important to monitor the status of conservation variables and the status of actual and possible threats. These threats may be biological or social in nature. Likewise, for effectiveness measurement, it is important to measure the conservation variable that the interventions are targeting and the threats and opportunities that may influence that variable. In addition, practitioners should consider the intervention, the management process behind it, and the various independent or confounding variables that may affect the intervention's success. Moreover, for status assessment, and for effectiveness measurement in particular, it is important to involve key stakeholders in the M\&E process because they can offer greater insight into what is actually happening.

The most basic lesson here is that it is important to understand the strengths and limitations of quantitative and qualitative methods and measures and to know when it is most appropriate to use each of them. For example, quantitative data are particularly useful for showing trends or comparing sites and strategies, whereas qualitative data help to explain the context of those trends. Practitioners should be clear about their information needs and gather the minimum amount of information required to meet these needs given the available resources. 


\section{Taking Action}

Based on these general lessons, there are at least five immediate areas for action. First, there is a need for greater collaboration among the conservation community. History shows that a vast array of individual M\&E efforts has only led to confusion about competing approaches, to duplication of efforts, and to a failure to learn from experience. To truly advance the field, the conservation community needs to work collectively and support the type of collaboration undertaken by groups such as the Montreal Process and CMP. More specifically, it is important for conservation practitioners to agree on the key steps and guiding principles for effective monitoring and evaluation-an area where CMP has already made considerable progress (CMP 2003c). In developing and implementing standards, however, it is important not to be sidetracked by nuances inherent in differing approaches (e.g., terminology and ordering of steps), but rather to agree more generally on common steps, underlying principles, and guidelines. Which specific approach an organization uses is less important than its adherence to these underlying principles and guidelines. Likewise, the conservation community would benefit from greater agreement on "short lists" of potential indicators for common conservation targets or values and more strategic selection of programmatic indicators of success. Programmatic indicators, however, should not be drawn from the laundry-list efforts of the past. Instead, these indicators should be the result of a process to identify measures that clearly relate to programmatic goals, objectives, and activities and that show progress along a causal chain toward the desired conservation state.

In addition, the conservation community needs to act on clearly defining M\&E terms used by different organizations in their specific approaches. Although it is important not to get lost in the nuances of terminology in agreeing on a common process for conducting M\&E, it is also important to recognize that the current inconsistent use of M\&E language has led to much confusion in the conservation community and beyond. The results from the work of CMP (2003b) will help to clarify the similarities and differences among approaches and will provide a model for cross-referencing M\&E terms. It is important that these types of efforts to create greater understanding and facilitate communication about M\&E continue.

A third area for action relates to the need to clarify the different components of an M\&E system and the unique purposes they serve. Table 4 offers a starting point for discussion within the conservation community. What is most important is that practitioners understand the function behind different M\&E components and use them accordingly.

Similarly, conservation practitioners need to understand when and where it is most appropriate to use the different available M\&E approaches. Table 1 highlights the strengths and weaknesses associated with these approaches. This table could be taken a step further if the conservation community were to develop a more formal process (e.g., a decision tree) to help managers decide which approaches best suit their needs.

Finally, because conservation takes place in a complex, human society, it always involves or is influenced by people. As such, the conservation community should consider social, economic, political, and cultural variables in its monitoring efforts and incorporate the use of qualitative data where feasible and useful. Conceptual frameworks provide a structure for considering these varied threats and opportunities and should be expanded to recognize factors beyond the biological realm. Moreover, there is a need for practitioner training in the use of conceptual frameworks, the development of conceptual models, and the application of both quantitative and qualitative research methods (but see Vayda [1997] for a critique of conceptual models). We hope that this review will generate broader discussion and help move the field of conservation closer to identifying the most appropriate and effective approaches to measure conservation success under varying conditions.

\section{Acknowledgments}

We thank the many individuals and organizations that have contributed to this work. In particular, we thank the following individuals we interviewed for generously sharing their knowledge of monitoring and evaluation in the conservation field: T. Hammond (IUCN); M. Hockings (IUCN World Commission on Protected Areas); J. Loh (WWF-UK); S. O'Connor (WWF International); D. Salzer (TNC); and D. Wilkie (Wildlife Conservation Society [WCS]). We are also grateful for the helpful feedback and attention to detail the following people provided us in reviews of this study: S. Christiansen (WWFUS); M. Hockings (IUCN World Commission on Protected Areas); E. Kennedy (Conservation International); K. Redford (WCS); and D. Salzer (TNC). M. Hockings and D. Salzer graciously and generously provided extensive input throughout this study. Finally, we thank the Gordon and Betty Moore Foundation for their generous support of the Measuring Conservation Impact Study.

\section{Literature Cited}

Bagri, A., and F. Vorhies. 1997. Biodiversity impact assessment. Draft discussion paper for SBSTTA3. World Conservation Union, Gland, Switzerland.

Banff National Park of Canada. 2003. Banff National Park of Canada: state of the park report. Parks Canada, Banff, Alberta.

Barrow, C. J. 1997. Environmental and social impact assessment: an introduction. Edward Arnold, London.

Blann, K., and S. S. Light. 2000. The path of last resort: adaptive environmental assessment and management (AEAM). Adaptive Management Practitioners' Network, Minneapolis, Minnesota. 
Brooke, C. 1998. Biodiversity and impact assessment. Prepared for the Conference on Impact Assessment in a Developing World. Royal Society for the Protection of Birds (RSPB)/BirdLife International, Manchester, United Kingdom.

Canadian International Development Agency. 1999. Results-based management in CIDA: an introductory guide to the concepts and principles. Canadian International Development Agency, Hull, Quebec.

Chelimsky, E., and W. R. Shadish, editors. 1997. Evaluation for the 21st century. Sage Publications, Thousand Oaks, California.

Clark, T. W., R. P. Reading, and A. G. Backhouse. 1995. Prototyping for successful conservation: the eastern barred bandicoot program. Endangered Species Update 12:5-7.

Conservation International. 2001. Rapid assessment program. Conservation International, Washington, D.C.

CMP (Conservation Measures Partnership). 2003a. Conservation Measures Partnership-charter declaration. CMP, Washington, D.C.

CMP (Conservation Measures Partnership). 2003b. Lexicon and Rosetta Stone of project management systems. CMP, Washington, D.C.

CMP (Conservation Measures Partnership). 2003c. Open standards for the practice of conservation. CMP, Washington, D.C.

Council on Environmental Quality. 1993. Incorporating biodiversity considerations into environmental impact analysis under the National Environmental Policy Act. Council on Environmental Quality, Washington, D.C.

Cracknell, B. E. 2000. Evaluating development aid: issues, problems, and solutions. Sage Publications, Thousand Oaks, California.

den Heyer, M. 2001. Literature review from: the development of a temporal logic model. University of Guelph, Guelph, Ontario.

Ervin, J. 2002. Rapid assessment and prioritization of protected area management. Worldwide Fund for Nature (WWF International), Gland, Switzerland.

Gotsch, C. 1998. Project appraisal. Stanford University, Stanford, California. Available from http://www.stanford.edu/group/FRI/indonesia/ courses/manuals/appraisal/Output/appraisalTOC.html (accessed December 2003).

Hatry, H. P. 1999. Performance measurement: getting results. Urban Institute Press, Washington, D.C.

Herweg, K., K. Steiner, and J. Slaats. 1998. Sustainable land management: guidelines for impact monitoring. Centre for Development and Environment, Berne, Switzerland.

Hockings, M. 2003. Systems for assessing the effectiveness of management in protected areas. BioScience 53:823-832.

Hockings, M., S. Stolton, N. Dudley, and J. Parrish. 2001. The enhancing our heritage toolkit: evaluating effectiveness training manual. University of Queensland, Gatton, Queensland.

Lee, K. N. 1993. Compass and gyroscope: integrating science and politics for the environment. Island Press, Washington, D.C.

Locally Managed Marine Areas Network. 2003. LMMA: improving the practice of marine conservation. Locally Managed Marine Areas Network, Suba, Fiji. Available from http://www.lmmanetwork.org/ (accessed December 2003).

Margoluis, R., and N. Salafsky. 1998. Measures of success: designing, managing, and monitoring conservation and development projects. Island Press, Washington, D.C.

Margoluis, R., V. Russell, M. Gonzalez, O. Rojas, J. Magdaleno, G. Madrid, and D. Kaimowitz. 2001. Maximum yield? Sustainable agriculture as a tool for conservation. Biodiversity Support Program, Washington, D.C.

Mark, M. M., G. T. Henry, and G. Julnes. 2000. Evaluation: an integrated framework for understanding, guiding, and improving policies and programs. Jossey-Bass, San Francisco.

Millennium Ecosystem Assessment Secretariat. n.d. Millennium ecosystem assessment: ecosystems and human well-being. Millennium Ecosystem Assessment, Penang, Malaysia.

Organisation for Economic Co-Operation and Development (OECD). 1993. OECD core set of indicators for environmental performance reviews. Environment monographs 83. OECD, Paris.

Overseas Environmental Cooperation Center. 2000. Environmental impact assessment for international cooperation: furthering the understanding of environment impact assessment systems for experts engaged in international cooperation activities. Environment Agency, Government of Japan, Tokyo.

Parks Canada. 1998. State of the parks 1997 report. Parks Canada, Ottawa.

Patton, M. Q. 1997. Utilization-focused evaluation: the new century text. 3rd edition. Sage Publications, Thousand Oaks, California.

Rigby, D., D. Howlett, and P. Woodhouse. 2000. Sustainability indicators for natural resource management and policy: a review of indicators of agricultural and rural livelihood sustainability. University of Manchester, Manchester, United Kingdom.

Salafsky, N., R. Margoluis, and K. Redford. 2001. Adaptive management: a tool for conservation practitioners. Biodiversity Support Program, Washington, D.C.

Salzer, D., and N. Salafsky. 2003. Allocating resources between taking action, assessing status, and measuring effectiveness. Working paper. The Nature Conservancy and Foundations of Success, Arlington, Virginia.

Sauer, J. R., J. E. Hines, and J. Fallon. 2001. The North American breeding bird survey, results and analysis 1966-2000. Version 2001.2. U.S. Geological Survey Patuxent Wildlife Research Center, Laurel, Maryland.

Sawhill, J., and D. Williamson. 2001. Measuring what matters in nonprofits. The McKinsey Quarterly 2:98-107.

Sayre, R., E. Roca, and G. Sedaghatk. 2000. Nature in focus: rapid ecological assessment. Island Press, Washington, D.C.

Stolton, S., M. Hockings, and N. Dudley. 2002. Reporting progress at protected area sites. World Bank/WWF Forest Alliance, Bristol, United Kingdom.

Swenson, R., J. Marty, K. Whitener, B. Waegell, and M. Eaton. 2002. Auditing progress on conservation by design: Cosumnes River Project, Central Valley Ecoregion (California). The Nature Conservancy, Sacramento, California.

The Montreal Process. 1999. Criteria and indicators for the conservation and sustainable management of temperate and boreal forests. The Montreal Process, Ottawa, Canada. Available from http://www. mpci.org/rep-pub/1999/ci_e.html (accessed December 2002).

TNC (The Nature Conservancy). 1999. Site consolidation scorecard manual. TNC, Arlington, Virginia.

The Nature Conservancy's (TNC) Developing Strategies Group, The Nature Conservancy's Measures \& Audit Team, and Foundations of Success. 2003. The enhanced 5-S project management process: an overview of proposed standards for developing strategies, taking action, and measuring effectiveness and status at any scale. TNC, Arlington, Virginia.

U.S. Environmental Protection Agency (EPA). 1999. Environmental outcome-based management: using environmental goals and measures in the Chesapeake Bay Program. EPA Region 3, Chesapeake Bay Program, Annapolis, Maryland.

U.S. Environmental Protection Agency (EPA). 2003a. Performance partnership. EPA, Washington, D.C. Available from http://www.epa.gov/ ocirpage/nepps/ (accessed June 2003).

U.S. Environmental Protection Agency (EPA). 2003b. EPA's volunteer monitoring program. EPA, Washington, D.C. Available from http:// www.epa.gov/owow/monitoring/volunteer/epasvmp.html (accessed September 2003).

U.S. National Environmental Policy Act of 1969. (Pub. L. 91-190, 91st Congress, Jan. 1, 1970).

Vayda, A. P. 1997. Managing forests and improving the livelihoods of forest-dependent people: reflections on CIFOR's social science research in relation to its mandate for generalisable strategic research. Working paper \# 20. Center for International Forestry Research (CIFOR), Bogor, Indonesia. 
Woodhill, J. 2000. Planning, monitoring and evaluating programmes and projects: introduction to key concepts, approaches and terms. World Conservation Union, Gland, Switzerland.

World Bank. 1997. Expanding the measure of wealth: Indicators of environmentally sustainable development. The World Bank, Washington, D.C.
Worldwatch Institute. 1984. State of the world 1984. Worldwatch Institute, Washington, D.C.

Worldwatch Institute. 2003. State of the world 2003. Worldwatch Institute, Washington, D.C

WWF (World Wildlife Fund) Australia. 1997. Marine protected areas report card. WWF Australia, Sydney.

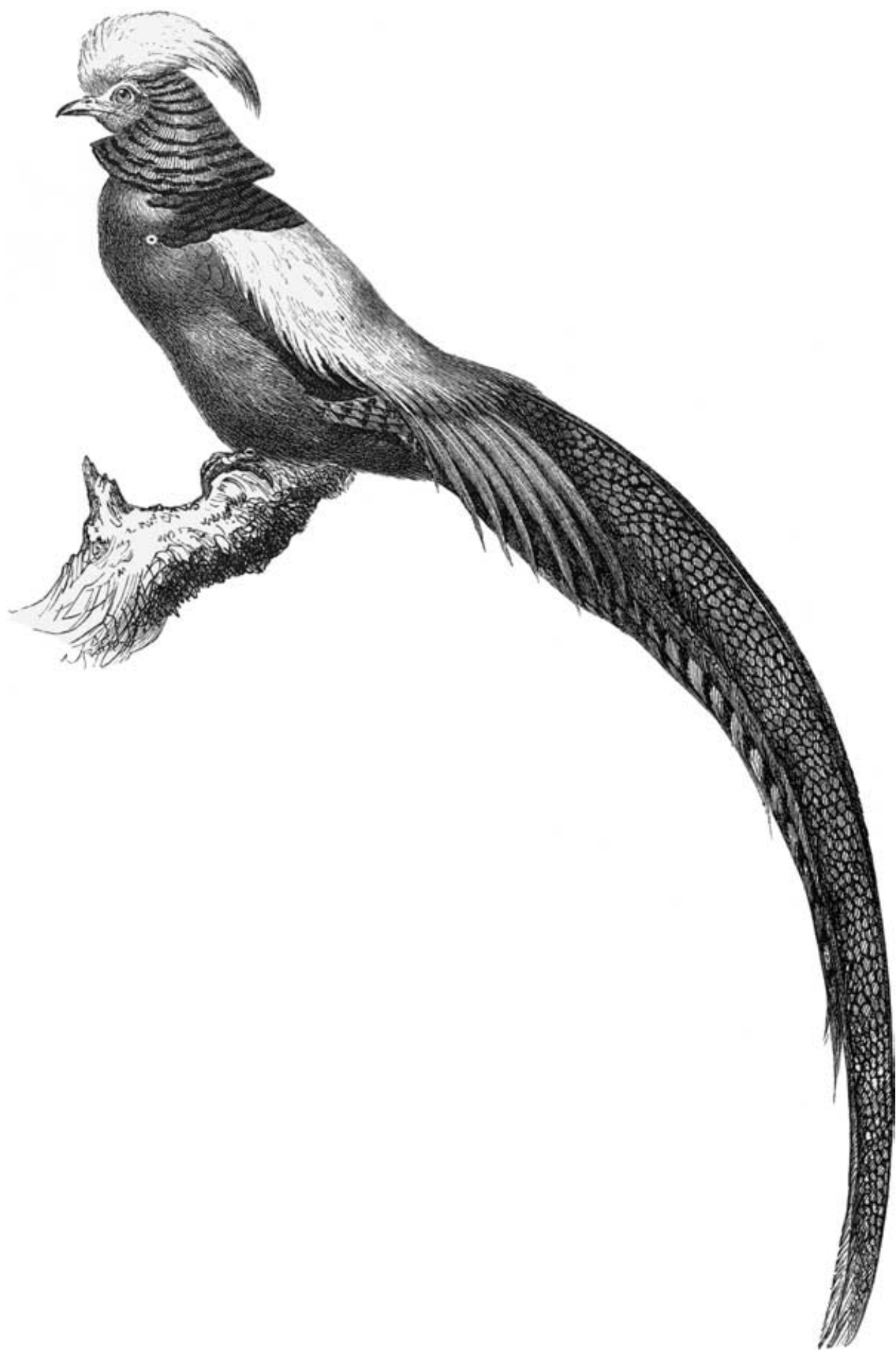

